\title{
DEDICATION
}

\section{Beyond the 'Moment of Abolition': Louk Hulsman 1923-2009 Phil Scraton}

Speaking at the Twelfth International Conference on Penal Abolition (ICOPA XII) Thomas Mathiesen (2008, p. 58) commented that penal abolitionists should feel neither "desperate" nor "ashamed" that they "could not stop the strong wave towards punitive populism, media panics and rising prison figures". Abolitionists had not contributed to the expansion of the prison system, they had not been "preoccupied... with system justification" or its refinement (ibid). "Abolitionism", he stated, "is a stance... the attitude of saying "no"... fostering and developing ... a deeply critical attitude to prisons and penal systems as human (and inhumane) solutions" (ibid, pp. 5859). Thomas Mathiesen argued further that abolitionism "goes beyond the parameters or conditions of existing systems" (ibid, p. 59). Negotiating reform of one "aspect" of the system draws the reformer into the presumption of the "necessity of maintaining the regime" (ibid). In saying "no" to prisons there is no truck with negotiation and no risk of incorporation into the punitive state's agenda: the ever expanding, global dominance of the prison-industrial complex.

Thomas Mathiesen completed his talk reflecting on the strength of collaborative work between academics, practitioners, campaigners and prisoners committed to building activist networks to resist the tide of penal populism. I turned to my long-time friend Louk Hulsman. Both indebted to Thomas Mathiesen's (1974) defining text, The Politics of Abolition, we exchanged glances of shared recognition. I recalled reading Rebecca Roberts' recent interview with Louk. He told her:

In learning about criminal justice I learned about the police and knew about the legislation and then I learned about the prison. I had been in prison because I had been arrested in the war and had been in a concentration camp and had all those experiences. Then, at a certain moment - you understand, I did not know how to organise all that knowledge, I could not do something with all that knowledge in those frameworks. Then I read Thomas Mathiesen - Politics of Abolition... I thought, 'I have to reorganise all my knowledge about it. You cannot in that language of criminal justice - you cannot discuss criminal justice in the language of 
criminal justice'. That was the moment of abolition. I thought 'I have to do what he is saying there'. (Roberts 2007, pp. 14-15).

Certainly, reading The Politics of Abolition shaped my understanding of prison in the context of the language and administration of criminal justice. At the time I was teaching a criminology class in Walton Prison, Liverpool. I was appalled by the conditions, overcrowding, warehousing and inhumanity of a regime controlled by abusive, aggressive and occasionally brutal guards. A lack of constructive and creative opportunities was compounded by endless hours and days when men were locked down in twos or threes in cells built in Victorian times to accommodate one prisoner. They were compelled to defecate in each other's presence, the stench so overwhelming that newspaper packages were pushed through the barred windows, dropping to the concrete below. Each morning, prisoners shovelled the contents into wheelbarrows. They were the prison's 'shit detail'. How could this place claim rehabilitation? How could prisoners return to their communities in a better physical and psychological state than they entered? On the contrary, prisons were debilitating, damaging and destructive. Prisons failed on their own terms.

The question of what prisons were for went deeper, to engage the social, political and economic constructions of 'crime', 'criminality' and 'criminal justice'. In 1986, Louk Hulsman wrote an article arguing against the traditional conceptualisation of 'crime' in which 'criminal events' were considered 'exceptional', 'criminal conduct' was addressed as "the most important cause of these events" and 'criminals' were perceived as a "special category of people" (Hulsman 1986, p. 63). He continued:

The public debate about the criminal justice system (c.j.s.) and its possible reform, almost always takes place in our (Western) type of society, within this limited framework. Proposals for reform take for granted that the c.j.s. must become better equipped to 'deal with social problems which are defined as offences'. Furthermore, one should minimize as much as possible the social costs of this method and distribute them as justly as possible. In addition, the impression exists... that the development of the criminal law is one of slowly progressing humanisation (ibid).

Louk Hulsman focused on the silencing of informed debate due to the assumed hostility of intolerant 'public opinion', and its popular representation and amplification in the news media. In the U.K., while moral panics occasionally flared, prisons were depicted as soft options providing opportunities for prisoners denied to many outside the walls. Yet, as Louk 
Hulsman noted, within the criminal justice system institutional confinement and cooperation between its constituent elements placed it beyond the 'control' of those in whose name it operated: "[ $t]$ his is particularly alarming, since the typical products of the system are the infliction of suffering and stigmatisation" (ibid, p. 64). How well this resonated with my experiences inside prisons where guards took every opportunity to obstruct any meaningful contact between outsiders and prisoners. Their purposeful promotion of a 'them' (criminals / prisoners) and 'us' (law-abiding / guards) mentality broadcast an unequivocal message to all who showed the slightest empathy or consideration to the incarcerated. Benevolent, caring outsiders were viewed unreservedly by guards as liberals, as betrayers of the 'good' and apologists for 'evil'.

Yet it is clear, as I felt at the time, that those "involved in "criminal" events do not in themselves to form a special category of people" (ibid, p. 65). In fact, most people at some point contravene the criminal law and would, if caught and prosecuted, be ascribed the label 'criminal'. Further, "nothing... distinguishes those "criminal" events intrinsically from other difficult or unpleasant situations" (ibid). A "considerable proportion of the events which would be defined as serious crime within the context of the c.j.s. remain completely outside that system" (ibid, p. 66). Thus, he concluded, "there is "no ontological reality" of crime". As Nils Christie (1998, p. 121) commented some years later:

Acts are not, they become. So it is with crime. Crime does not exist. Crime is created. First there are acts. Then follows a long process of giving meaning to those acts.

Following a sharply critical analysis of and challenge to 'new realist' criminology, particularly its subscription to 'conventional wisdoms on crime', Louk Hulsman's (1986, p. 67) endeavour was to "reorganise the debate within criminology and criminal policy" with the intention of achieving "the abolition of criminal justice as we know it". A central proposition was that in any form, a "criminology which continues to incorporate in its own "language" the concepts which play a key role in this [criminal justice] process, can never take an external view on this reality and is therefore unable to demystify it" (ibid, p. 71). For criminology to be critical it must abandon the "definitional activities of the system" including the "notion of 'crime'... [which] is not the object but the product of criminal policy" (ibid). 
"Criminalisation", therefore, names and outlaws "a certain occurrence or situation as undesirable"; attributes it to an individual, responds with "social control: the style of punishment". Its operational location requires a "special organizational setting": criminal justice. Whatever the criminal justice response, its negotiation sidelines the victim and perpetrator leaving resolution to criminal justice "professionals, whose main interest is not related to the original event, but their daily work in criminal justice" (ibid, p. 72). Nodding seemingly in the direction of Durkheim, Louk Hulsman noted the error in responding to "problematic situations" as if they "could be eradicated in social life" (ibid, p. 73). He continued:

They are part of life. People need problematic situations in the same way as food and air. More important than to prevent problematic situations is to try to influence societal structures in such a way that people can cope and deal with problems in a way which permits growth and learning and avoids alienation (ibid).

Within the broader debate about 'crime' and 'criminal justice' Louk Hulsman's contribution to understanding and progressing abolitionism in the context of critical analysis has been considerable. Social action, interaction and reaction are complex. Meanings attributed at any stage of an emerging or consolidating 'problem' depend on the location of individuals and collectives. While classical criminological theories focused on causation, critical analyses emphasise context - the 'frame of interpretation' and the 'focus' of definition. By identifying and understanding the political-economic and socio-cultural contexts of defining, targeting and regulating 'crime' critical analyses challenge the pathological model that informs correction and punishment. It reveals the pre-eminence attributed to criminalisation at the expense of real alternatives of negotiation, mediation and arbitration.

In consolidating his critical 'stance' Louk Hulsman (1986, pp. 78-79) provided the key 'tasks' for critical criminology:

... continue to describe, explain and demystify the activities of criminal justice and its adverse social effects... abandoning 'behavior' and deviance as a starting point for analysis and adopting instead a situationoriented approach, micro and macro. Illustrate... how in a specific field problematic situations could be addressed at different levels of the societal 
organisation without having recourse to criminal justice. Study strategies on how to abolish criminal justice... contribute to the development of another overall language in which questions related to criminal justice and to public problems which generate claims to criminalisation, can be discussed without the bias of the present 'control babble'.

Such 'problematic situations' can only be identified, understood and addressed by locating the experiential world of everyday life within the structural relations of power, authority and legitimacy. Critical criminology accepts that people are active agents to an extent mapping in their destinies. They make choices, think differently, act spontaneously, interact responsively and react on impulse or with considered judgement. As 'agents', they also resist the imposition of controls and regulations. They organise, campaign and collectivise their actions in social movements. Yet structural relations, along with the interventions of state and private institutions set boundaries to social interaction and personal opportunity. Nowhere is this more evident than in law enforcement, criminal justice and punishment.

Rather than accepting 'crime' and 'antisocial behaviour' as outcomes of individual pathology, weak socialisation or social dysfunction in a fair, equal and just meritocracy, critical analysis challenges administrative criminology and proposes that the overarching structural relations of advanced capitalism, patriarchy, neo-colonialism and age are inherently conflictual and subjugating. The ownership and control of the means of production and distribution, the politics and economics of reproduction as well as normative heterosexuality, the colonial legacies of racism and xenophobia along with the exclusion of children and young people from active participation, in both private and public spheres, reveal determining contexts that have consequences for all people in society. Power and authority are not limited to material (economic) or physical (force) interventions but are supported by deep-rooted ideologies - a social force of compliance and conformity. The populist appeal of authoritarianism, often connected to folk devils, demonisation and moral panics, is a tangible manifestation of social forces. It smoothes the pathway to prison, ensuring that few politicians will acknowledge openly the prison as an indefensible, institutionalised discriminatory utility geared to 'manage' marginalised and alienated 'problem' populations.

In a later paper, Louk Hulsman (1991, p. 21) commented on the "sad results of the [abolitionist] movement to introduce and develop alternatives to penal sanctions". Specifically, he noted Stan Cohen's (1985, p. 37) 
observation that, in part, within the criminal justice system "there has been an intensification, complication and extension" of the "early $19^{\text {th }}$ century master patterns... rationalization, centralization, segregation, classification". Rather, the "alternatives had merely left us with wider, stronger and different nets" (ibid, p. 39). Returning to his central position, Louk Hulsman argued that this reflected a failure to shift the debate on alternatives away from the 'premises of criminal justice'. Yet he refused to be pessimistic in the face of consolidating authoritarianism. Academics, he argued, "should not strive to play the role of the intellectual-prophet who tells people what they have to do, who prescribes the frames of thought, objectives and means which he/she develops in his/her head, working in the study surrounded by [their] tools" (Hulsman 1991, p. 32):

No, the role of the academic is to show (1) how institutions really function, (2) [identify] the real consequences of their functioning in the different segments of social formations... (3) [identify] the systems of thought which underline these institutions and their practices... show[ing] the historical contexts of these systems, the constraint they exercise on us and the fact that they have become so familiar to us, that they are part of our perceptions, our attitudes and our behaviour. At last (4) he/she has to work with those directly involved practitioners to modify the institutions and their practices and to develop other forms of thought. (ibid).

Louk Hulsman's objective was not to provide a range of practical interventions as alternatives but 'to offer a conceptual system' as a foundation on which 'to contextualize the ideas on alternatives to criminal justice and the concrete projects developed in many countries which are founded on such ideas ...' (ibid). He concluded:

[T]o make progress in the field of alternatives we have to abandon the cultural and social organisation of criminal justice. Criminal justice is perpetrator-oriented, based on blame-allocation and on a last judgment view on the world. It therefore does not provide us with information and a context in which, in an emancipatory way, problematic situations can be defined and dealt with (ibid).

This position has been associated with the shift towards restorative justice as an alternative to criminal justice. It emphasises negotiated outcomes fully informed by the perspectives of all involved or affected by troubling 
behaviour. It moves towards forms of arbitration that focus on harm rather than 'crime', on circumstances rather than 'blame' and on outcomes other than 'punishment'.

In my last conversation with Louk Hulsman, I raised the issue of the almost evangelical zeal accompanying restorative approaches linked directly, via police or youth justice agencies, to criminal justice. Concerned by their proximity to the principles of criminal justice, their failure to recognise the structural relations of power and their claims to alternative disposals, I described the adversarial atmosphere in which children and young people as perpetrators can be confronted by victims, their families and community members. Apart from noting the implicit contradiction of setting restorative processes within a criminal justice context, he commented that the practitioners had not made the necessary personal transition to escape the intellectual confines of criminal justice ideology. I was reminded of his interview with Rebecca Roberts (2007, pp. 20-21):

\footnotetext{
Nearly everybody was raised to believe that those images which are behind criminal justice... are true. So then I begin to... say to people, 'we are criminal justice'. And abolition of criminal justice is that you abolish that in yourself, in the same way we are doing with racism and in the same way we are doing that with gender differences... You abolish criminal justice in yourself... Abolishing means that you will not anymore talk that language. And if you do not talk that language anymore then you see other things... it's like that - abolition.
}

In building 'strategies of decarceration' towards penal abolition Angela Davis (2003, p. 103) identifies the "major challenge" of working towards "more humane, habitable environments for people in prison without bolstering the permanence of the prison system". Abolition, she argues is a "constellation of alternative strategies and institutions" prioritising "demilitarization of schools, revitalization of education at all levels, a health system that provides free physical and mental health care to all, and a justice system based on reparation and reconciliation rather than retribution and vengeance" (ibid, p. 107). Given the resilience of the politics and ideology of incarceration, as well as the global expansion of the lucrative prisonindustrial complex it is difficult to envisage significant advances towards Angela Davis's objectives. Louk Hulsman, however, was not deflected or deterred by the disappointments he had witnessed: 
You see, if I look at my own experience... because I live for more or less a century - I am 84 now... You can really say the $20^{\text {th }}$ century is my century... I have judged the things in that century. It's very interesting when you have such a large space to see all the things... all the things you have seen change. When you look in such a sort of way... you know that things can change very fast... I am firmly convinced that nobody knows about the future... We should certainly not think that criminal justice could not be abolished (Roberts, 2007, p. 36).

When we last met, Louk and I planned for his visit to Belfast during summer 2009 prior to the European Group for Deviance and Social Control's annual conference. We talked of the thirteenth ICOPA conference in Belfast scheduled for 2010. As ever, our conversations fluctuated between work, travel, families and happy reminiscences. Alongside his intellectual qualities, Louk's generosity of spirit, mischievous humour and infectious laughter defined him. I was about to leave for Sydney when I received news of the death of my friend. Over the next days he was constantly in my thoughts and, with my partner Deena, we remembered the times we shared. On a cool summer day in New South Wales we walked a deserted strand, the sea thundering ashore.

The $32^{\text {nd }}$ Wave

At Bherwerre where the ocean crashes

Over the solitary five mile strand

I'm sure I heard your voice...

Beyond the thirty-second wave.

Kayakers will tell you that's the one

That swells and rises, surely and calmly,

Emerging purposefully with force and passion

Its crest glints sharply with grace and dignity

Dancing ashore to move hearts and minds

That was the moment your laugh was with us

Pitched, as always. above the maelstrom

Generous and warm, forever Louk,

Taking hold of the thirty second wave.

Booderee

NSW, Australia

15 February 2009 


\title{
REFERENCES
}

Christie, Nils (1998) "Between Civility and the State", in Vincenzo Ruggiero, Nigel South and Ian Taylor (eds.), The New European Criminology: Crime and Social Order in Europe, London: Routledge, pp. 119-124.

Cohen, Stanley (1985) Visions of Social Control, Cambridge: Polity Press.

Davis, Angela (2003) Are Prisons Obsolete?, New York: Seven Stories Press.

Hulsman, Louk (1991) "Alternatives to Criminal Justice: Decriminalization and Depenalization”, in Lasocik Zbigniew, Monika Platek and Irena Rzeplinska (eds.), Abolitionism in History: On Another Way of Thinking, Warsaw: Warsaw University, pp. 21-34.

Hulsman, Louk (1986) "Critical Criminology and the Concept of Crime", Contemporary Crises, 10: 63-80.

Mathiesen, Thomas (2008) "Response: The Abolitionist Stance", Journal of Prisoners on Prisons, 17(2): 58-63.

Mathiesen, Thomas (1974) The Politics of Abolition, London: Martin Robertson.

Roberts, Rebecca (2007) What happened to Abolitionism? An Investigation of a Paradigm and Social Movement, Unpublished MSc Thesis, London: Department of Social Policy - London School of Economics.

\section{About the Author}

Phil Scraton is Professor of Criminology, Institute of Criminology and Criminal Justice, School of Law, Queen's University, Belfast. His latest books are Power, Conflict and Criminalisation (Routledge, 2007), The Violence of Incarceration (edited with Jude McCulloch - Routledge, 2008), Hillsborough: The Truth (Mainstream, 2009), and The Incarceration of Women (with Linda Moore - Palgrave Macmillan, forthcoming). He is deeply grateful to the editors for the opportunity to write for the Journal. He can be contacted via e-mail at p.scraton@qub.ac.uk or by post at the following address:

\author{
Phil Scraton \\ Queen's University Belfast \\ 28 University Square - Room 28.102 \\ Belfast, BT7 1NN \\ Northern Ireland, UK
}

